\title{
ANALISIS PENGARUH TRANSPORTASI ONLINE TERHADAP KESEMPATAN KERJA DAN KESEJAHTERAAN DI KOTA MEDAN
}

\author{
Eka Purnama Sari*, Talia Yuedrika** \\ *Universitas Potensi Utama, Medan, Email: purnamaeka35@gmail.com \\ ** Universitas Potensi Utama, Medan, Email: talia.rieka@gmail.com
}

\begin{abstract}
This study aims to determine the influence of online transportation on employment opportunities and welfare in Medan City. The method used is a quantitative approach based on the path analysis with a simple linear regression analysis model. The results of the study showed that around $64,9 \%$ variables of online transportation explained by changes in variables of employment opportunities and welfare in in Medan City, while the test $35,1 \%$ is explained by other factors. About $33,4 \%$ of the variables of online transportation affected by employment opportunities and around 31.5\% of the online transportation variables affected the welfare variable. The significance of the indirect test results indicates that there was an indirect effect of the variable online transportation on welfare through employment opportunities significantly. The impact of this study is there is a significant influence on employment opportunities and community welfare in in Medan City with an Online Motorcycle taxi that can absorb labor and increase the income of UMKM through various services available in the online motorcycle taxi application.
\end{abstract}

Keywords: Online Motorcycle Taxis, Job Opportunities, Welfare

\begin{abstract}
Abstrak
Penelitian ini bertujuan untuk mengetahui bagaimana pengaruh transportasi online terhadap kesempatan kerja dan kesejahteraan di Kota Medan. Metode yang digunakan yaitu pendekatan kuantitatif dengan menggunakan analisis jalur dengan model analisis regresi linier sederhana. Secara simultan hasil penelitian menunjukkan bahwa sekitar $64,9 \%$ variabel transportasi online mempengaruhi kesempatan kerja dan kesejahteraan di kota Medan, sedangkan 35,1\% dijelaskan oleh faktor-faktor lain. Sedangkan secara parsial sekitar 33,4\% variabel transportasi online mempengaruhi kesempatan kerja dan sekitar 31,5\% variabel transportasi online mempengaruhi variabel kesejahteraan. Hasil uji signifikansi pengaruh tidak langsung menunjukkan adanya pengaruh tidak langsung dari variabel transportasi online terhadap kesejahteraan melalui kesempatan kerja secara signifikan. Adapun dampak penelitian ini yaitu terdapat pengaruh yang signifikan terhadap kesempatan kerja dan kesejahteraan masyarakat di Kota Medan dengan adanya Ojek Online yang dapat menyerap tenaga kerja dan meningkatkan pendapatan para UMKM melalui berbagai layanan yang ada di aplikasi ojek online.
\end{abstract}

Kata Kunci: Ojek Online, Kesempatan Kerja, Kesejahteraan 


\section{PENDAHULUAN}

Di setiap negara pasti melaksanakan pembangunan demi mewujudkan masyarakat yang sejahtera dan makmur, sehingga meningkatkan pertumbuhan ekonomi suatu negara. Hal ini dapat dilakukan dengan cara mengatasi masalah seperti tingkat kesejahteraan masyarakat. Menurut Adi (2012:87) kesejahteraan merupakan suatu kondisi dimana seseorang tersebut dapat memenuhi kebutuhan pokoknya, baik makanan, tempat tinggal, pakaian, sampai kemampuan untuk dapat melanjutkan pendidikan hingga pekerjaan yang memadai untuk menunjang kualitas hidup.

Adiwarman (2008:318) juga berpendapat bahwa indikator dari kesejahteraan seseorang itu dapat dilihat apabila terpenuhi jika kebutuhannya sendiri dan keluarganya tercukupi dari segi materi dan juga kebutuhan spritual, hal tersebut di ukur dari tercukupkannya kebutuhan pokok yaitu sandang, pangan, papan dan juga kebutuhan beribadahnya. Sehingga kesejahteraan merupakan kemampuan memenuhi seluruh kebutuhan baik jasa maupun barang yang memang dianggap penting dalam kehidupan.

Tak hanya itu, hak yang dapat menghambat pertumbuhan ekonomi suatu negara juga dapat dilihat dari masalah pengangguran atau sedikitnya kesempatan dan peluang kerja yang ada di suatu negara. Padahal, dengan jumlah penduduk yang tinggi dapat menjadi suatu aset yang sangat berharga dalam meningkatkan kemakmuran bangsa. Dengan berbagai keanekaragaman kebutuhan menunjukkan betapa tingginya permintaan terhadap hasil suatu produksi. Sementara itu tinggi rendahnya hasil produksi sangat tergantung pada faktor tenaga kerja. Salah satu kuncinya yaitu kesesuaian antara berbagai keahlian yang dimiliki penduduk dengan peluang/kesempatan kerja yang tersedia.

Permasalahan dalam kesempatan kerja ini, juga berkaitan dengan masalah ketenagakerjaan dimana masyarakat yang tidak memiliki pekerjaan atau belum mendapatkan kesempatan kerja biasa atau sering disebut dengan pengangguran.

Beberapa tahun belakangan ini, perkembangan bisnis dibidang jasa sangat marak dan berkembang pesat dibeberapa negara dan kota salah satunya Kota Medan. Salah satu terobosan yang paling dimanti adalah jasa transportasi online atau ojek online.

Dengan munculnya terobosan transportasi online ini, banyak kelebihan yang dapat dinikmati oleh pengguna seperti lebih cepat di dapat karena dapat diakses dimana saja menggunakan GPS dan dapat melewati dan mengurangi sela kemacetan dikarenakan GPS dapat memberikan informasi rute tercepat dan terdekat. Tak han- 
ya itu, transportasi online ini juga sudah dilengkapi dengan tarif sehingga pengguna mengetahui berapa tarif yang akan dibayar sesuai dengan tujuan yang dikehendaki. Kelebihan yang ditawarkan inilah yang membuat transportasi online semakin dikenal oleh masyarakat dan juga banyak diminati di kota besar terkhusus Kota Medan.

Tidak sampai distu saja, dengan adanya transportasi online ini juga memberikan dampak yang baik bagi masyarakat yang belum mendapatkan kesempatan kerja sehingga ini merupakan peluang kerja sebagai pekerja tetap maupun sampingan bagi masyarakat.

Menurut kepala Badan Pusat Statistik (BPS) Suhariyanto yang dikutip oleh Antaranews (2016), ojek online membantu menurunkan angka pengangguran di beberapa daerah. "Naiknya jumlah angkutan ojek motor dan angkutan bermotor lainnya ikut mempengaruhi turunnya angka pengangguran di beberapa daerah.

Sedangkan menurut keterangan Kepala BPS dan Republika, ojek online berpengaruh terhadap pengangguran di Indonesia. Meningkatnya permintaan jasa ojek online mengakibatkan peningkatan permintaan tenaga kerja pengemudi ojek online. Permintaan tenaga kerja pengemudi ojek online ini berpengaruh terhadap kondisi pengangguran di Indonesia.

Salah satu daerah yang terkena imbasnya dari kehadiran Ojek online ini adalah Kota Medan. Kota ini yang merupakan kota metropolitan terbesar ketiga di Indonesia setalah Jakarta dan Surabaya. Di kota ini banyak hiruk pikuk kehidupan di berbagai bidang. Dengan pesatnya perkembangan kota ini membuat banyak orang yang menggunakan jasa ojek online untuk berpergian ketempat kerja dan kemana pun mereka inginkan. Dengan adanya ojek online ini akan lebih mudah dan efisien dalam menjangkau lokasi.

Gambar 1. Penduduk Miskin di Kota Medan 2010-2017

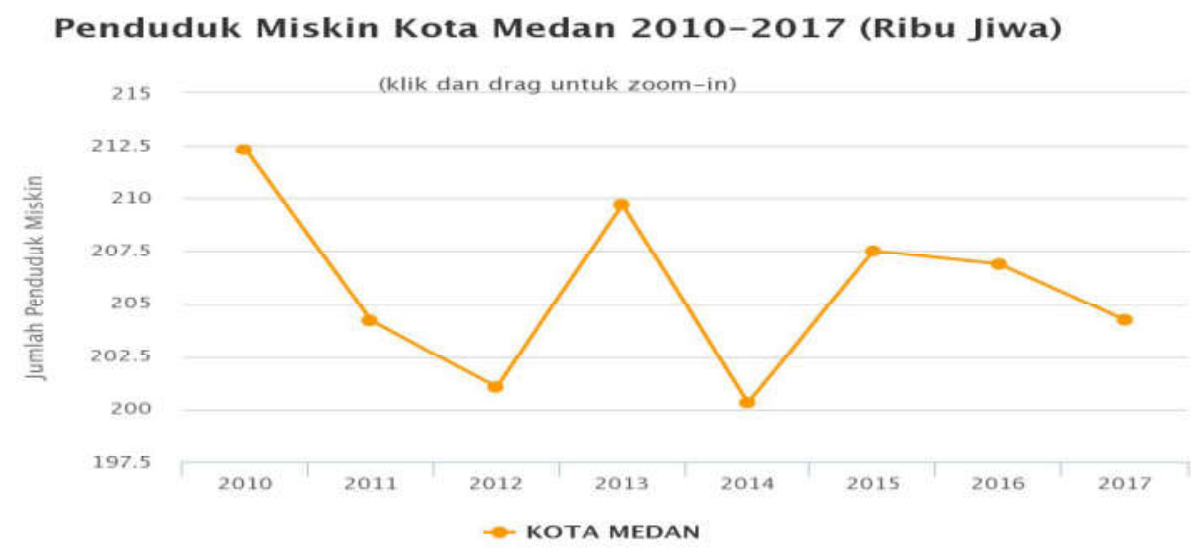

Sumber: bpskotamedan.go.id diakses pada 14/03/2018 
Dari grafik di atas dapat dilihat bahwa tingkat penduduk miskin di Kota medan dari tahun 2010-2017 mengalami penurunan yang sangat signifikan. Kehadiran transportasi online di Kota Medan pada tahun 2016, terlihat bahwa dari tahun 2016 ke tahun 2017 tingkat kemiskinan di kota Medan semakin berkurang. Hal ini merupakan salah satu indikasi dengan adanya kehadiran transportasi online tersebut yang menyerap tenaga kerja menjadi meningkat sesuai dengan permintaan perusahaan transportasi online.

Selain menjemput dan mengantarkan penumpang, Ojek online juga dapat memperdayakan UMKM di Kota Medan yang sebelumnya tidak produktif menjadi produktif dengan menghubungkan pemilik UMKM dan pemilik keterampilan dengan konsumen yang membutuhkan. Misal, Go-Jek menyediakan jasa antar tukang urut yaitu Go-Massage dan pembantu yaitu Go-Clean sehingga keterampilan mengurut dan membersihkan rumah yang dimiliki seseorang dapat diproduktifkan. Go-Jek menyediakan jasa Go-Auto yaitu jasa antar montir sehingga bisnis bengkel atau keterampilan seseorang dalam memperbaiki kendaraan bermotor dapat diproduktifkan.

Go-Jek juga menyediakan jasa Go-Med yaitu jasa antar obat dari Apotik ke konsumen. Terakhir, Go-Jek dan Grab menyediakan jasa antar makanan yaitu Go-Food dan GrabFood sehingga membantu UMKM yang bergerak dibidang makanan untuk terhubung dengan pelanggannya.

Dari sekian banyak layanan ojek online yang diluncurkan masing-masing perusahaan terlihat bahwa setiap stakeholder yang terkait mendapatkan kebermanfaatan dengan adanya ojek online ini. Masyarakat yang sebelumnya tidak memiliki pekerjaan, sekarang sudah memiliki pekerjaan menjadi driver ojek online. Hal ini memberi dampak yang positif yaitu memberikan kesempatan kerja bagi yang belum memiliki pekerjaan dan akan mengurangi tingkat pengangguran disuatu daerah. Selain itu dengan adanya pekerjaan tersebut, masyarakat mampu memenuhi kebutuhan mereka sehari-hari. Bahkan banyak dari mereka yang mendapatkan pendapatan yang lebih sehingga mereka bisa menginvestasikan pendapatannya. Ini menunjukkan perkembangan dan perubahan yang pesat yang akan menyejahterakaan bagi keluarga kecilnya dan akan menaikkan tingkat kesejahteraan di Kota Medan. Hal ini berkaitan dengan alquran surah Al-Qashash ayat 84 yang berbunyi:

“Barangsiapa yang datang dengan (membawa) kebaikan, maka baginya (pahala) yang lebih baik daripada kebaikannya itu; dan barangsiapa yang datang dengan (membawa) kejahatan, maka tidaklah diberi pembalasan kepada orang-orang yang telah mengerjakan kejahatan itu, melainkan (seimbang) dengan apa yang dahulu mereka kerjakan."

Dari ayat tersebut terlihat bahwa bagi yang datang dengan membawa kebaikan 
maka akan memperoleh balasan pahala yang lebih baik daripada kebaikannya dan sebaliknya. Kehadiran ojek online ini memberikan manfaat bagi semua kalangan masyarakat. Namun tidak semua masyarakat kota Medan yang mau menerima kehadiran ojek online tersebut. Kehadirannya menimbulkan kontroversi baik yang pro dan kontra. Bagi kalangan driver konvensional mereka menolak dengan alasan mengambil alih rezeki yang selama ini mereka dapatkan. Penumpang transportasi konvensional semakin sedikit karena beralih ke transportasi online dan pendapatan mereka semakin hari semakin berkurang. Dan jika dikaitkan dengan islam tentang rezeki maka rezeki masing-masing orang sudah diatur Allah SWT, hanya saja bagaimana caranya untuk menjemput rezeki tersebut. Sesuai alquran surat Hud Ayat 6:

Artinya: “...... dan tidak satu pun makhluk bergerak di bumi melainkan dijamin Allah rezekinya" (Surah Hud, ayat 6).

Jelas bahwa jaminan rezeki dari Allah SWT pada mahkluk-Nya adalah jaminan yang pasti lagi benar untuk menunjukkan betapa Maha Kaya Allah yang memiliki segala sifat kebesaran-Nya. Sehingga diperlukan regulasi pemerintah tentang aturan transportasi berbasis online yang tepat dan tidak memihak kepada satu pihak sehingga tidak ada yang dirugikan.

Motivasi dilakukan penelitian ini yaitu ingin mengetahui apakah dengan munculnya transportasi online beberapa tahun terakhir ini mampu untuk memberikan kesenpatan kerja yang besar dan juga bisa mensejahterakan masyarakat khususnya di Kota Medan. Beberapa hasil penelitian terdahulu seperti Antonius dan Lasma (2019) yang menyatakan bahwa transportasi online memiliki dampak positif terhadap penurunan angka pengangguran. Begitu juga dengan Rudy dan Erni (2018) menyatakan bahwa transportasi online berdampak positif bagi sosial ekonomi masayrakat di Samarinda.

Dari referensi penelitian terdahulu diatas, maka penulis tertarik untuk mencoba meneliti dengan variabel kesejahteraan masyarakat sebabgai variebel tambahan yang disesuaikan dengan tempat peneliti yaitu di Kota Medan.

Berdasarkan seluruh pemaparan latar belakang di atas, maka penulis Untuk lebih fokusnya penulis ingin mencoba melakukan penelitian langsung dengan judul “Analisis Pengaruh Transportasi Online Terhadap Kesempatan Kerja dan Kesejahteraan Di Kota Medan ". 


\section{LANDASAN TEORI}

\section{Kesejahteraan}

Kementerian Koordinator Kesejahteraan Rakyat memberi pengertian sejahtera yaitu suatu kondisi masyarakat yang telah terpenuhi kebutuhan dasarnya. Kebutuhan dasar tersebut berupa kecukupan dan mutu pangan, sandang, papan, kesehatan, pendidikan, lapangan pekerjaan, dan kebutuhan dasar lainnya seperti lingkungan yang bersih, aman dan nyaman. Juga terpenuhinya hak asasi dan partisipasi serta terwujudnya masyarakat beriman dan bertakwa kepada Allah SWT.

Perumusan konsep kesejahteraan oleh Biro Pusat Statistik (BPS) dan Badan Koordinasi Keluarga Berencana Nasional (BKKBN) mengatakan bahwa keluarga yang dikatakan sejatera apabila memenuhi kriteria berikut:

1) Keluarga yang dapat memenuhi kebutuhan anggotanya, baik kebutuhan sandang, pangan, perumahan, sosial maupun agama;

2) Keluarga yang mempunyai keseimbangan antara penghasilan keluarga dan jumlah anggota keluarga; dan

3) Keluarga yang dapat memenuhi kebutuhan kesehatan anggota keluarga, kehidupan bersama dengan masyarakat sekitar, beribadah khusuk di samping terpenuhi kebutuhan pokoknya.

\section{Kesempatan Kerja}

Menurut Tambunan (2001: 54) kesempatan kerja adalah jumlah orang yang dapat bekerja di suatu perusahaan yang menampung tenaga kerja sesuai dengan lapangan pekerjaan yang tersedia. Kesempatan kerja berhubungan dengan permintaan tenaga kerja, dimana semakin tinggi permintaan tenaga kerja oleh perusahaan atau instansi maka semakin tinggi juga kesempatan kerja yang ada, begitu juga sebaliknya semakin rendah permintaan tenaga kerja maka semakin rendah juga kesempatan kerja yang ada. Dalam penelitian ini, kesempatan kerja yang diteliti adalah kesempatan kerja yang ditimbulkan oleh adanya kehadiran TNC ojek online di kota Medan.

\section{Transportasi Online}

Menurut Papacostas, transportasi didefinisikan sebagai suatu sistem yang terdiri dari fasilitas tertentu beserta arus dan sistem control yang memungkinkan orang atau barang dapat berpindah dari suatu tempat ketempat lain secara efisien dalam setiap waktu untuk mendukung aktivitas manusia. 
Berdasarkan beberapa pengertian di atas maka, penulis berpendapat bahwa transportasi itu adalah suatu usaha pemindahan manusia atau barang dari satu tempat ketempat lainnya dalam waktu tertentu dengan menggunakan sebuah kendaraan yang digerakkan oleh manusia, hewan, maupun mesin.

Sedangkan pengertian online menurut M. Romli dalam bukunya adalah sebagai berikut, Media online adalah media massa yang tersaji secara online di situs web (website) internet. Berdasarkan pemaparan diatas maka, penulis mengartikan secara ringkas, Transportasi Online adalah perusahaan transportasi yang menggunakan aplikasi sebagai penghubung antara pengguna dan pengemudi yang sangat mempermudah pemesanan, selain itu juga tarif perjalanan sudah langsung bisa dilihat pada aplikasi.

Menurut Keputusan Menteri Perhubungan Nomor 35 Tahun 2003 tentang Penyelenggaraan Angkutan orang di jalan dengan kendaraan umum, Angkutan adalah "perpindahan orang dan/atau barang dari satu tempat ke tempat lain dengan menggunakan kendaraan".

Pada dasarnya keberadaan ojek sepeda motor sebagai kendaraan bermotor roda dua memiliki keunggulan dan keunikan tersendiri mengingat ojek bisa memberi layanan door to door, dapat menjangkau lokasi sulit seperti loronglorong dan jalan sempit, atau mampu melewati kemacetan. Namun ojek sepeda motor dikatakan angkutan umum ilegal, karena belum adanya aturan yang mengatur secara khusus mengenai ojek sepeda motor di dalam undang-undang. Keberadaan ojek sepeda motor sendiri bisa dikatakan sangat dibutuhkan oleh masyarakat.

Ojek sepeda motor dikatakan sebagai angkutan orang dengan kendaraan bermotor roda dua. Tidak diatur secara khusus mengenai sepeda motor sebagai angkutan kendaraan bermotor umum, karena ada beberapa permasalahan dalam administrasi pendaftaran ojek sebagai kendaraan bermotor umum di Dinas Perhubungan.

\section{METODE}

Populasi yang digunakan dalam penelitian ini adalah seluruh driver transportasi onlie (Grab dan Go-jek) yang ada di Kota Medan.

Sedangkan sampel dalam penelitian ini menggunakan Research Methods For Business yaitu "Bila dalam penelitian akan menggunakan alat analisis multivariate, maka jumlah anggota sampel minimal 10 kali dari jumlah variabel yang diteliti. Misalnya variabel penelitian ada 4 ( 3 independen +1 dependen), maka jumlah anggota 
sampel $=10 \times 4=40 "$.

Berdasarkan penentuan sampel tersebut, penenlitian ini menggunakan 3 variabel ( 2 independen +1 dependen) maka jumlah anggota sampel $=35$ × $3=105$ orang.

Teknik pengambilan sampel menggunakan teknik Accidental sampling, yaitu tekhnik penelitian sampel berdasarkan kebetulan yaitu memilih responden dengan cara mendatangi responden kemudian memilih calon responden, namun calon responden harus memiliki karakteristik tertentu yaitu driver yang nge-time dan memakai attribute Grab dan Go-Jek. Teknik analisis data pada penelitian ini menggunakan analisis korelasi, analisis regresi linier sederhana, uji t, serta analisis jalur.

\section{HASIL DAN PEMBAHASAN}

\section{Analisis Korelasi}

Analisis korelasi merupakan analisis untuk mengukur keeratan hubungan dua variabel yang mempunyai dua distribusi data normal. Dalam penelitian ini, analisis korelasi dilakukan untuk mengetahui sejauh mana korelasi atau derajat antara Transportasi Online terhadap Kesempatan Kerja dan Kesejahteraan.

\begin{tabular}{cllll}
\multicolumn{5}{c}{ Correlations } \\
\hline & $\begin{array}{c}\text { Transportasi } \\
\text { Online }\end{array}$ & $\begin{array}{c}\text { Kesempatan } \\
\text { Kerja }\end{array}$ & Kesejahteraan \\
\hline $\begin{array}{c}\text { Pearson Cor- } \\
\text { relation }\end{array}$ & Transportasi Online & 1.000 & .578 & .562 \\
& Kesempatan Kerja & .578 & 1.000 & .701 \\
& Kesejahteraan & .562 & .701 & 1.000 \\
Sig. (1-tailed) & Transportasi Online &. & .000 & .000 \\
& Kesempatan Kerja & .000 &. & .000 \\
& Kesejahteraan & .000 & .000 &. \\
\hline
\end{tabular}

Dari hasil analisis korelasi sederhana $(r)$ didapat korelasi antara transportasi online terhadap kesempatan kerja ( $\mathrm{r}$ ) adalah 0,578 dan korelasi transportasi online terhadap kesejahteraan ( $r$ ) adalah 0,562. Hal ini menunjukkan bahwa terjadi hubungan yang sedang (berada pada 0,40 - 0,599) antara transportasi online terhadap kesempatan kerja dan kesejahteraan. Hubungan korelasi sedang dikarenakan faktor lain yang tidak diteliti dalam penelitian ini. Sedangkan arah hubungan adalah positif karena nilai $r$ positif, berarti jika regulasi pemerintah terhadap transportasi online jelas serta insentif yang diberikan perusahaan transportasi online maka semakin besar kesempatan kerja dan semakin meningkat pula tingkat kesejahteraan masyarakat. 


\section{Analisis Regresi Linier Sederhana dan Uji Hipotesis (Uji t)}

Analisis Pengaruh Transportasi Online Terhadap Kesempatan Kerja

\begin{tabular}{|c|c|c|c|c|}
\hline Pengaruh langsung antar variabel & $\begin{array}{l}\text { Koefisien } \\
\text { jalur (pij) }\end{array}$ & $\begin{array}{l}\text { Kesalahan } \\
\text { baku (sbi) }\end{array}$ & t hitung & $p$-value \\
\hline$X$ terhadap $Y_{1}\left(p X Y_{1}\right)$ & .334 & .076 & 7.193 & .000 \\
\hline$X$ terhadap $Y_{12}\left(p X Y_{2}\right)$ & .315 & .071 & 6.889 & .000 \\
\hline$Y_{1}$ terhadap $Y_{2}\left(p Y_{1} Y_{2}\right)$ & .492 & .065 & 9.988 & .000 \\
\hline
\end{tabular}

Berdasarkan hasil penelitian bahwa pengaruh transportasi online terhadap kesempatan kerja di kota Medan sebesar 0,334\% dengan standar error 0,076 dan pengaruhnya signifikan dengan nilai t hitung 7.193 lebih besar dibandingkan dengan t-tabel 1,659, maka $\mathrm{H}_{0}$ ditolak dan $\mathrm{H}_{1}$ diterima, artinya terdapat pengaruh antara transportasi online dengan kesempatan kerja di kota Medan. Hal ini sejalan dengan penelitian yang dilakukan oleh LD FEB UI bahwa GO-JEK telah berkontribusi sebesar Rp 216 miliar rupiah per tahun. Turro menambahkan GO-JEK telah mengurangi angka penggangguran dengan memperluas kesempatan kerja.

Hal ini juga menunjukkan bahwa dengan hadirnya lapangan pekerjaan dengan menggunakan transportasi online ini telah mampu menjadi salah satu alternatif solusi dalam menekan angka pengangguran di karenakan telah membuka lapangan pekerjaan baru di kota Medan yang berdampak cukup baik untuk mengurangi tingkat pengangguran di kota Medan bahkan banyak dari para driver mengaku bahwa dengan adanya sistem transportasi online ini dan membantu menambah pendapatan mereka walaupun ada dasarnya sudah bekerja atau punya pekerjaan tetap.

\section{Analisis Pengaruh Transportasi Online Terhadap Kesejahteraan}

Bahwa pengaruh transportasi online terhadap kesejahteraan di kota Medan sebesar 0,315 dengan standar error 0,071 dan pengaruhnya signifikan dengan nilai t hitung 6.889 lebih besar dibandingkan dengan t-tabel 1.659, maka $\mathrm{H}_{0}$ ditolak dan $\mathrm{H}_{2}$ diterima, artinya terdapat pengaruh antara transportasi online dengan kesejahteraan di kota Medan.

Pada dasarnya keidealan dari kesejahteraan itu haruslah bersifat holistik dan juga seimbang, hal ini bermakna bahwa kecukupan materi yang didukung oleh terpenuhinya kebutuhan spiritual serta mencakup individu dan sosial. Sebab manusia tidak hanya hidup di alam dunia saja, tetapi juga di alam setelah kematian/kemusnahan dunia (akhirat). Kecukupan materi di dunia ditunjukkan dalam rangka untuk memperoleh kecukupan di akhirat. Jika kondisi ideal ini tidak tercapai maka kesejahteraan di akhirat tentu lebih diutamakan, sebab ini merupakan sesuatu yang abadi dan lebih bernilai (valuable) dibanding kehidupan dunia 
Dan hal ini juga menunjukkan bahwa dengan hadirnya lapangan pekerjaan dengan menggunakan transportasi online ini telah mampu mensejahterakan kehidupan para driver Gojek dan Grab beserta keluarganya baik secara fisik (yang tampak) ataupun yang bersifat batiniah seperti adanya kebebasan waktu beribadah.

Berdasarkan hasil penelitian ini, hipotesis yang didapat sependapat dengan penelitian yang dilakukan Hal ini sejalan dengan penelitian yang dilakukan oleh LD FEB UI mengatakan bahwa GO-JEK sumbangkan 334 miliar per tahun untuk perekonomian Kota Medan.

\section{Analisis pengaruh Kesempatan Kerja terhadap Kesejahteraan}

Nilai $r^{2}$ variabel $Y_{1}$ terhadap Variabel Y2 sebesar 0,492 atau 49,2\% artinya Kesejahteraan dipengaruhi oleh variabel kesempatan kerja dengan kontribusi sebesar 49,2\%. Dan berdasarkan hasil penelitian bahwa pengaruh tidak langsung transportasi online terhadap kesejahteraan melalui kesempatan kerja adalah sebesar 0,1643 atau sebesar $16,43 \%$ dan pengaruhnya signifikan dengan nilai t hitung 3,969, lebih besar dibandingkan dengan nilai t-tabel 1.659, maka $\mathrm{H}_{0}$ ditolak dan $\mathrm{H}_{3}$ diterima, artinya terdapat pengaruh tidak langsung transportasi online terhadap kesejahteraan melalui kesempatan kerja.

Dari hasil penelitian ini dapat disimpulkan bahwa hubungan antara hadirnya transportasi online ini sangat membantu para pengangguran ataupun yang sudah bekerja namun penghasilannya masih kurang mencukupi kebutuhan sehari-hari untuk mendapatkan pekerjaan dengan syarat yang cukup mudah dipenuhi dan menghasilkan pendapat yang mampu meningkatkan kesejahteraan pekerjanya.

Faktor yang mendorong driver tertarik untuk bekerja transportasi online antara lain melihat pada hasil, fleksibelitas jam kerja, bisa menjadi pekerjaan sampingan, bertambahnya teman atau lingkungan sosial, dan kebutuhan akan pekerjaan.

Pada dasarnya transportasi online ini juga mampu mengubah pola pandang orang yang pada umumnya terhadap tukang ojek menjadi lebih dihargai dimana ditunjukkan dengan minat masyarakat untuk menjadi driver ojek dan pendapatan yang menggiurkan.

Kontribusi sosial keberadaan ojek ada pada kontribusi dalam penyerapan tenaga kerja, penciptakan peluang pekerjaan dalam jumlah besar, alternatif pilihan pekerjaan, menciptakan status pekerjaan yang baru, alternatif pengisi waktu luang, kemandirian ekonomi, menciptakan peluang yang sama bagi siapa saja untuk mandiri secara ekonomi dengan modal yang tidak besar, melatih kemandirian sosial, mendorong perubahan sosial. 


\section{Analisis Jalur}

Pengaruh tidak langsung variabel eksogen terhadap variabel endogen, meliputi:

Pengaruh tidak langsung Transportasi online terhadap Kesejahteraan melalui Kesempatan Kerja $\left(X=>Y_{1}=>Y_{2}\right)$ adalah hasil kali koefisien jalur $P X Y_{1}$ dan $P Y_{1,} Y_{2}=$ $0,334 \times 0,492=0,1643$

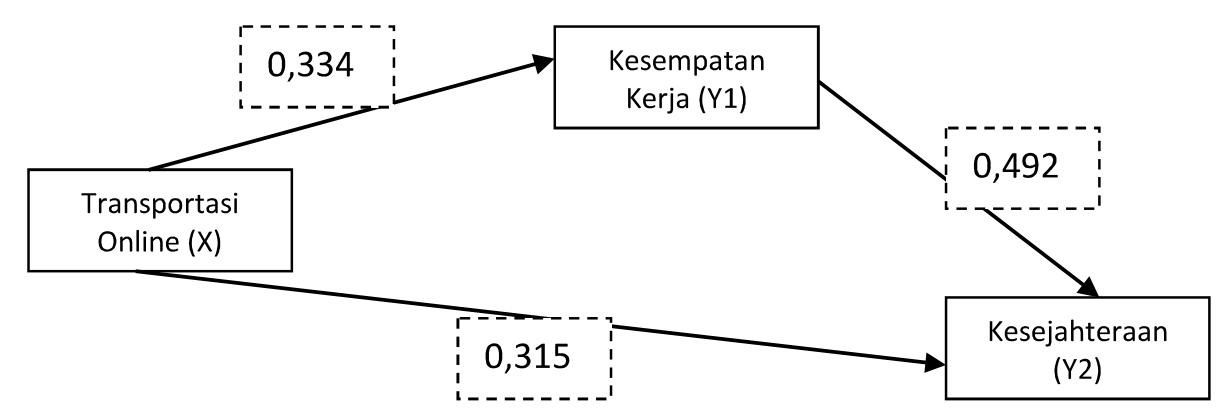

Untuk mengetahui signifikansi pengaruh indirect effect maka digunakan rumus z-statistik yang dikembangkan oleh Sobel sebagai berikut :

$z=\frac{a x b}{\sqrt{b^{2} x s_{a}^{2}+a^{2} x s_{b}{ }^{2}+s_{a}{ }^{2} x s_{b}{ }^{2}}}$

\section{Dimana :}

$a, b$ dan $c$ adalah nilai koefisien jalur

$\mathrm{s}_{\mathrm{a}}$ dan $\mathrm{s}_{\mathrm{b}}$ adalah standar error untuk $\mathrm{a}$ dan $\mathrm{b}$

Dalam hal ini, dasar pengambilan keputusan adalah dengan membandingkan t-tabel dengan z hitung. Data di atas diketahui dk (derajat kebebasan) = $105-3=102$ dengan taraf kepercayaan $\alpha=0,05$ maka t-tabel sebesar 1,659

Kriteria penilaian :

a. Jika nilai $z$ hitung $>t$ tabel maka indirect efet signifikan. Artinya adanya pengaruh inderect effect dari variabel eksogen terhadap variabel endogen melalui variabel moderating (intervening) secara signifikan atau nyata.

b. Jika nilai $z$ hitung < t tabel maka indirect efect tidak signifikan. Artinya tidak adanya pengaruh inderect effect dari variabel eksogen terhadap variabel endogen melalui variabel moderating (intervening).

Pengaruh tidak langsung $X$ terhadap $Y_{2}$ melalui $Y_{1}\left(X=>Y_{1}=>Y_{2}\right)$, Sabel test : 


$$
\begin{aligned}
\mathrm{Y} 1 & =\frac{0,334 \times 0,492}{\sqrt{(0,492)^{2} \times(0.076)^{2}+(0,334)^{2} \times(0,065)^{2}+(0.076)^{2} \times(0,065)^{2}}} \\
\mathrm{Y} 1 & =\frac{0,16432}{\sqrt{(0,2420 \times 0,0057)+(0,1115 \times 0,0042)+(0,0057 \times 0,0042)}} \\
\mathrm{Y} 1 & =\frac{0,16432}{\sqrt{0,0013+0,0004+0,00002}} \\
\mathrm{Y} 1 & =\frac{0,16432}{\sqrt{0,00172}} \\
& =3,96414
\end{aligned}
$$

Sehingga diperoleh bahwa Y1 lebih besar dari t-tabel atau 3,969 > 1,659, maka dapat diambil kesimpulan bahwa adanya pengaruh tidak langsung transportasi online terhadap kesejahteraan melalui kesempatan kerja yang signifikan dengan tingkat kepercayaan $95 \%$ atau tingkat kesalahan $5 \%$.

\section{SIMPULAN}

Berdasarkan hasil analisis data yang telah dikemukakan sebelumnya, maka dapat ditarik kesimpulan yaitu:

1). Pengaruh langsung transportasi online terhadap kesempatan kerja dan kesejahteraan di kota Medan adalah sebagai berikut:

2). Hasil analisis regresi pengaruh langsung menunjukkan variabel transportasi online memberikan kontribusi sebesar 33,4\% terhadap kesempatan kerja. Serta sebesar $31,5 \%$ variabel transportasi online memberikan kontribusi terhadap kesejahteraan. Artinya setiap peningkatan penambahan jumlah driver ojek online baik gojek maupun grab akan meningkatkan tingkat kesejahteraan di kota Medan. Hal ini terlihat kemunculan gojek dan grab di Kota Medan pada tahun 2016 secara tidak langsung mengurangi tingkat kemiskinan dikota Medan.

3). Dengan adanya transportasi berbasis online banyak masyarakat menjadi driver grab dan gojek terbukti dengan banyaknya pengemudi terlihat hampir diseluruh sudut kota. Selain dijadikan pekerjaan tetap, banyak masyarakat yang menjadikan gojek dan grab sebagai pekerjaan tambahan. Hal ini terjadi karena penghasilan dari driver lebih menguntungkan dan menjanjikan. Disamping itu masyarakat 
yang belum memiliki pekerjaan sekarang sudah memiliki perkerjaan dengan adanya transportasi online masa kini. Sehingga perlu adanya peran pemerintah dalam mengatur regulasi tentang aturan yang tepat dan efisien sehingga tidak merugikan transportasi online (gojek dan grab) dengan transportasi konvensional (angkot dan becak). Dengan adanya aturan yang jelas antara kedua transportasi ini maka driver transportasi online dan konvensional akan nyaman dan tidak saling baku hantam dalam mencari rezeki dan menjalankan pekerjaannya masing-masing.

4). Pengaruh tidak langsung transportasi online terhadap kesejahteraan melalui kesempatan kerja sebesar 0,1643 atau sebesar 16,43\% dan pengaruhnya signifikan dengan nilai t hitung 3,969, lebih besar dibandingkan dengan nilai t-tabel 1,659, maka Ho ditolak dan Ha diterima, artinya terdapat pengaruh tidak langsung transportasi online terhadap kesejahteraan melalui kesempatan kerja. Dengan adanya transportasi online maka secara tidak langsung akan meningkatkan kesejahteraan masyarakat dikota medan. Setelah Perusahaan gojek dan grab masuk ke kota Medan maka akan membuka lapangan pekerjaan. Masyarakat yang awalnya belum mempunyai pekerjaan setelah menjadi mitra gojek dan grab maka mereka bias menghidupi keluarga nya serta setelah sekian lama menjadi mitra hidup para driver gojek dan grab sangat sejahtera.

\section{PUSTAKA ACUAN}

Arikunto. 2006. Prosedur Penelitian Suatu Pendekatan Praktek Jakarta : PT. Rineka Cipta.

Azwar, Saifuddin. 2007. Metode Penelitian.Yogyakarta: Pustaka Pelajar

Bellante D et al. 1990. Ekonomi Ketenagakerjaan. Jakarta (ID): LPFEUI.

Dumairy. 1997. Perekonomian Indonesia, Penerbit Erlangga, Jakarta.

Departemen Tenaga Kerja dan Transmigrasi. 2003. Undang-Undang Nomor 13 Tahun 2003 Tentang Ketenagakerjaan. Medan (ID): Departemen Tenaga Kerja dan Transmigrasi.

Hadi, Sutrisno, 2006, Analisis Regresi, Yogyakarta: Andi Offset.

Hall JV et al. 2015. An Analysis Of The Labor Market For Uber's Driver-Partner In The United States.

N. Martono, Metode Penelitian Kuantitatif: Analisis Isi dan Analisis Data Sekunder (sampel halaman gratis): RajaGrafindo Persada, 2010

Nicholson W. 1998. Microeconomic Theory Basic Prinsiples and Extensions. Massachussetts(US): The Dryden Pr. 
Michael P. Todaro, 2006. Economic Development, Jakarta: Erlangga.

Mishalani et al. 2011. "Real-Time" Ridesharing- The Oppurtunities and Challenges of Utilizing Mobile Phone Technology to Improve Rideshare Services.

Regidor JRF et al. 2016. Comparative Analysis of Transportation Network Companies (TNC's) and Conventional Taxi Services in Metro Manila.

Roscoe, J.T. 1975. Fundamental Research Statistics for the Behavioural Sciences, 2 nd edition. New York: Holt Rinehart \& Wilnaton.

Simanjuntak PJ. 1998. Pengantar Ekonomi Sumber Daya Manusia. Jakarta (ID):LPFEUI

Suprayitna, Iwan. 2016. BPS: Ojek Online Bantu Turunkan Pengangguran, KOMPAS, 7 November 2016.

Tambunan, Tulus TH.2001. Transformasi Ekonomi di Indonesia. Jakarta (ID): Salemba Empat.

Undang-Undang Nomor 11 Tahun 2009 Tentang Kesejahteraan Sosial

Wallsten S. 2015. The Competitive Effect of the Sharing Economy: How is Uber Changing Taxis

https://sumut.bps.go.id/ diakses pada 14 Maret 2018

https://pustaka.bkkbn.go.id diakses pada 14 Maret 2018

hubdat.dephub.go.id/uu/288-uu-nomor-22-tahun-2009-tentang-lalu.../download

hubdat.dephub.go.id/km/tahun-2003/194-km-35-tahun-2003 